\title{
Pentingnya Materi Lingkungan Terhadap Pembelajaran Bahasa Indonesia
}

\author{
Ayu Puji Lestari \\ ayupujilestari310799@gmail.com
}

Dalam kehidupan lingkungan memiliki peran yang sangat penting. Materi lingkungan dapat dikaitkan dengan pembelajaran bahasa Indonesia. Dalam pembelajaran bahasa Indonesia materi lingkungan sangat penting, sebab dengan mempelajari materi lingkungan peserta didik akan memiliki pemahaman yang baik tentang materi lingkungan, sehingga peserta didik memiliki kepekaan dan kepedulian terhadap lingkungan, terutama lingkungan kelas pada saat pembelajaran bahasa Indonesia.

Lingkungan adalah mencangkup segala hal yang ada dik sekitar kita. Menurut Lai CS ( dalam Ramadhan, et al, 2019) mengatakan bahwa "environmental problems are inherently inseparable from environmental awareness, values, and attitudes of people. This encourages countries to start assessing environmental education”. Masalah lingkungan pada dasarnya tidak dapat dipisahkan dari kesadaran lingkungan, nilai-nilai, dan sikap masyarakat. Hal ini mendorong negara untuk mulai menilai pendidikan lingkungan." Salah satu masalah yang sering terjadi adalah kebersihan lingkungan sekitar. Masyarakat kurang menyadari bahwa tindakannya tersebut bisa merusak lingkungan. Menurut Cokcaliskan dan Celiko (dalam Ramadhan at al, 2019) individu harus didorong untuk tidak memandang lingkungan sebagai sesuatu yang harus dieksploitasi untuk tujuan mereka, tetapi sebagai aseta yang berharga yang harus dilindungi demi kelangsungan hidup manusia.

Menurut Buldur dan Omeroglu ( dalam Ramadhan, et al, 2019) guru berperan penting dalam pengajaran pendidikan lingkungan dan menumbuhkan kesadaran siswa tentang lingkungan. Selain itu, Begman B,G (dalam Ramadhan et al,2019), berhubungan dengan itu guru juga memiliki peranan yang penting dalam mengajarkan materi lingkungan kepada siswa. Guru juga harus mengembangkan kemampuan siswa dalam memahami, mengkritik, dan berpartisipasi secara rasional dalam setiap wacana tentang masalah lingkungan. Menurut Jacobs G M dan Cates K ( dalam Ramadhan et al, 2019), tujuan dari pendidikan lingkungan adalah untuk membuat siswa berpartisipasi dalam melindungi lingkungan adalah membuat siswa berpatisipasi dalam melindungi lingkungan. 
Materi lingkungan yang diajarkan di sekolah maupun di perguruan tinggi merupakan kebijakan para ahli pendidikan yang perlu dipuji, dengan mempelajari materi lingkungan dari dini, baik dari sekolah maupun perguruan tinggi dapat menumbuhkan kepedulian akan pentingnya dan melestarikan lingkungan masing-masing. Menurut Unyar dan Ensar (dalam Ramadhan et al,2019) penggunaan tema lingkungan dalam pembelajaran teks dapat memicu minat belajar bahasa siswa dan secara implisit dapat meningkatkan pengetahuan siswa tentang lingkungan. Selain itu, (Ramadhan, et al, 2019) juga mengemukan pendidikan lingkungan penting untuk meningkatkan sikap dan kesadaran siswa terhadap lingkungan.

Menurut Obasoro,Olinloye, dan Ilensami (dalam Ramadhan et al,2019), siswa perlu memiliki pengalaman yang baik dalam memahami dan mengatasi setiap perubahan global dan lingkungan masyarakat. Menurut Kollmuss A dan Agyeman J, Schultz P W, Shriver C, Tabanico J J, dan Khazian A M, Xehua Z, serta Çokçaliskan H and Çelik Ö ( dalam Ramadhan et al, 2019), agar siswa berpatisipasi dalam melindungi lingkungan, penting untuk mengembangkan pengetahuan tentang lingkungan, kesadaran lingkungan dan perubahan perilaku terhadap lingkungan

Berdasarkan permasalahan di atas, penulis telah menyebarkan angket mengenai pentingnya materi lingkungan terhadap pembelajaran bahasa Indonesia yang ditujukan kepada mahasiswa S1 dari berbagai jurusan, universitas dan juga jenis kelamin. Penelitian yang dilakukan adalah dengan membuat sepuluh pertanyaan tentang pentingnya materi lingkungan dalam bahasa Indonesia dalam bentuk angket google form. Hasil yang didapatkan dari penelitian itu adalah sebagai berikut.Pertanyaan pertama, dalam pembelajaran bahasa Indonesia materi lingkungan sangat penting, 57,4\% menyatakan sangat setuju dan 42,6\% menyatakan setuju. Pertanyaan kedua, dalam pembelajaran bahasa Indonesia, materi-materi yang bertemakan lingkungan merupakan salah satu strategi untuk menambah kosakata, 37\% menyatakan sangat setuju dan 63\% menyatakan setuju. Pertanyaan ketiga, dalam pembelajaran bahasa Indonesia guru mengajak siswa untuk lebih mencintai lingkungan sekitar, 57,44\% menyatakan sangat setuju dan 42,6\% menyatakan setuju. Pertanyaan keempat, materi lingkungan dalam pembelajaran bahasa Indonesia berkaitan dengan penggunaan bahasa Indonesia dalam kehidupan sehari-hari, 52,8\% menyatakan sangat setuju dan 47,2\% menyatakan setuju. Pertanyaan kelima, dalam pembelajaran bahasa Indonesia materi lingkungan berkaitan dengan lingkungan sosial, 
lingkungan alam, dan lingkungan hidup, 51,9\% menyatakan sangat setuju dan 48,1\% menyatakan setuju. Pertanyaan keenam, materi lingkungan dalam pembelajaran bahasa Indonesia bertujuan untuk terjadinya proses komunikasi atau interaksi antara siswa dan lingkungan, 57,4\% menyatakan sangat setuju dan 42,6\% menyatakan setuju. Pertanyaan ketuju, saat pembelajaran bahasa Indonesia guru harus mengajak siswa untuk menjaga dan melestarikan lingkungan, 59,3\% menyatakan sangat setuju dan 40,7\% menyatakan setuju. Pertanyaan kedelapan, materi tentang lingkungan dalam pembelajaran bahasa Indonesia membuat siswa peduli akan kebersihan lingkungan, 50\% menyatakan sangat setuju dan 50\% menyatakan setuju. Pertanyaan kesembilan, keuntungan adanya materi lingkungan dalam pembelajaran bahasa Indonesia adalah siswa dapat menghargai dan menjaga lingkungan dengan baik, 40,7\% menyatakan sangat setuju dan59,3\% meyatakan setuju. Dan pertanyaan terakhir, materi lingkungan dalam pembelajaran bahasa Indonesia sangat dianjurkan bagi siswa, 50\% menyatakan sangat setuju dan $50 \%$ menyatakan setuju.

Berdasarkan hasil penelitian penulis diatas dapat disimpulkan bahwa materi lingkungan dalam pembelajaran bahasa Indonesia memang sangat penting, dengan adanya materi lingkungan peserta didik akan semakin menjaga dan melestarikan lingkungannya, menumbuhkan sikap peka terhadap situasi dan kondisi lingkungan sekitar dan membangun karakter yang jujur, disiplin, empati, dan optimis serta religius. Tulisan ini bertujuan agar masyarakat dan peserta didik dapat menjaga kelestarian lingkungan.

\section{Daftar Rujukan}

Bergman, B.G. (2016). Assessing impacts of locally designed environmental education projects on students' environmental attitudes, awareness, and intention to act Environmental Education Reseach 22(4) 480-503

Buldur, A. and Ömeroglu, E. (2018). An examination of the relationship between preschool children's and their teacher' attitute and awareness towards the environment Journal of Education and Learning 7(2) 221-9

Cokcaliskan H and Celiko (2017). Investigation of pre-service classroom teacher's awareness and attitudes International Electrinic Journal of Environmental Education 7(2) $73-83$ 
Çokçaliskan H and Çelik Ö (2017). Investigation of pre-service classroom teachers' environmental awareness and attitudes International Electronic `Journal of Environmental Education 7 73-83

Jacobs G M and Cates K.(2012). Global education in second language and teaching. International Journal of Physical and Social Sciences 2 1-22

Kollmuss A and Agyeman J. (2002). Mind the gap: Why do people act enviconmentally and what are the barriers to pro-environmental behavior Environmental Education Research $239-60$

Lai, C.S. (2018). A study of fifth graders environmental learning outcomes in Taipel International Journal Of Research In Education and Science 4(1) 252-61

Ramadhan, S., Sukma, E., \& Indriyani, V. (2019). Environmental education and disaster mitigation through language learning. IOP Conference Series: Earth and Environmental Science, 314

Schultz P W, Shriver C, Tabanico J J and Khazian A M. (2004). Implicit connections with nature Journal of Environmental Psychology 24 (1) 31-42

Xuehua Z.(2004) An overview of the environmental knowledge system for elementary school students Chinese Education and Socie 37(4) 45-7 